PETER LIPAR, Ph.D. ${ }^{1}$

(Corresponding author)

E-mail: peter.lipar@fgg.uni-lj.si

IRENA STRNAD, B.Eng. ${ }^{1}$

E-mail: irena.strnad@fgg.uni-lj.si

MARTIN ČESNIK, B.Eng.

E-mail: martin.cesnik@gmail.com

TOMAŽ MAHER, Ph.D. ${ }^{1}$

E-mail: tomaz.maher@fgg.uni-lj.si

1 University of Ljubljana, Faculty of Civil and Geodetic

Engineering, Traffic Technical Institute

Jamova cesta 2, 1000 Ljubljana, Slovenia
Traffic in the Cities

Preliminary Communication

Submitted: Aug. 13, 2015

Accepted: Apr. 12, 2016

\title{
DEVELOPMENT OF URBAN DRIVING CYCLE WITH GPS DATA POST PROCESSING
}

\begin{abstract}
This paper presents GIS-based methodology for urban area driving cycle construction. The approach reaches beyond the frames of usual driving cycle development methods and takes into account another perspective of data collection. Rather than planning data collection, the approach is based on available in-vehicle measurement data post processing using Geographic Information Systems to manipulate the excessive database and extract only the representative and geographically limited individual trip data. With such data post processing the data was carefully adjusted to include only the data that describe representative driving in Ljubljana urban area. The selected method for the driving cycle development is based on searching for the best microtrips combination while minimizing the difference between two vectors; one based on generated cycle and the other on the database. Accounting for a large random sample of actual trip data, our approach enables more representative area-specific driving cycle development than the previously used techniques.
\end{abstract}

\section{KEY WORDS}

driving cycle; microtrips; driving pattern; exhaust emissions; fuel consumption; frequency distribution;

\section{INTRODUCTION}

The combustion of fossil fuels in internal combustion engines results in exhaust emissions that are caused by road transport. The congestion that occurs in any urban area on a daily basis and the specific driving pattern that involves frequent acceleration and deceleration as well as long stops, results in the presence of high concentrations of pollutants. High pollution levels can be reduced by limiting exhaust emissions in the most exposed areas, which indicates the need for accurate emission level assessment. Exhaust emission and fuel consumption can be modelled based on the driving cycle. In Slovenia, a representative driving cycle has not yet been established. Levels of exhaust emissions can therefore be assessed only by using one of the standard driving cycles obtained in other environments that may not be suitable for describing the local conditions, and may therefore result in inaccurate emission levels. To obtain a good approximation of emission levels and develop an emission model, accurate driving cycle development that is representative for a particular region is crucial in order to reflect the actual driving patterns and take into account the specific environment.

Research has been undertaken in the last years to develop representative real-world driving cycles aimed at modelling emission. A common set of reference real-world driving cycles for the European area within the European $5^{\text {th }}$ Framework project: ARTEMIS - Assessment and Reliability of Transport Emission Models and Inventory Systems [1] has been designed and can be used for modelling emissions. However, several studies have shown that driving patterns vary significantly around the world due to unique topography and driving behaviour in each city, resulting in the need for area-specific driving cycles [2-7]. Emission analyses [8-10] have been performed based on the developed driving cycles that provided a good insight into the possibilities of influencing emissions with alternative fuels. However, a part of some emission analyses is the development of a new driving cycle to describe driving conditions realistically [11-14].

Many works focused on driving cycle construction methods. A comprehensive review of basic methodologies of cycle construction is presented in [15], which distinguishes four types of cycle construction methods based on the type of driving activity that is being used to construct the cycle: micro-trip cycle construction, trip segment-based cycle construction, cycle construction based on pattern classification, and modal cycle construction. Bishop et al. [16] and Brady et al. [17] used a robust, data-driven Markov Chain method to 
capture real-world behaviour in a driving cycle without deconstructing the raw velocity-time sequence.

The first step to all of the methods is collecting real world driving data $[1,15]$. A review provided by Tong [18] distinguishes two basic data collection methodologies; chase car technique and on-board measurement technique. Another approach is microsimulation modelling instead of data collection [19], where the quality of the driving cycle depends heavily on the quality of the microsimulation. Our approach is to some extent in line with on-board measurement technique; however, it differs significantly from the previous data collection methods. Contrary to the usual approach with predetermined paths, the vehicles travelled according to the drivers' needs; our database therefore, consists of large random sample of trip data.

The main objective of the research presented in this paper is to develop a representative driving cycle for a specific urban area based on an available database which consists of in-vehicle measurements, provided in the research "PAMS Activity Monitoring of Light-Duty Vehicles: Recruitment of vehicles in the region of Ljubljana (Slovenia)," carried out by the University of Ljubljana, the Faculty of Civil and Geodetic Engineering, the Traffic Technical Institute (UL FGG PTI) in cooperation with the Joint Research Center (JRC), the European Commission's science service [20].

The presented research consisted of describing data collection method, GPS data post-processing and analysis using Geographic Information Systems or, shortly, GIS. The next step was driving cycle construction procedure. The developed driving cycle is presented and compared to the standard driving cycles. Finally, the developed driving cycle was used to quantify and discuss vehicles emissions in Ljubljana urban area in comparison to the standard driving cycles.

\section{METHODOLOGY}

\subsection{Data collection and analysis}

\subsubsection{Measurements}

Driving cycles are based on "time - speed" relationship; therefore, the development of an accurate driving cycle requires a large sample of representative trip data. A part of the aforementioned research [20] included obtaining in-vehicle measurements with Portable Activity Monitoring System (PAMS). Nineteen personal vehicles from different manufacturers, engine displacements and fuel types were equipped for taking measurements in Slovenia (Table 1). The paths of the vehicles were not predetermined, so the vehicles travelled randomly, in accordance with the traveller's needs. The drivers' characteristics were different (different gender, age and employment status) to consider various driving behaviours of real-world drivers.

The vehicles were equipped with on-board measurement module that incorporates an OBD II diagnostics interface, a GPRS/GMS module and a GPS position tracking system. The collected data is transmitted to a server with GPRS/GMS module that provides the data for post processing and analysis. OBD II interface provides data on: OBD I| velocity, OBD II RPM $1 / 4$ (revolution per minute), OBD II load (engine load), OBD II consumption (fuel consumption). GPS position tracking system provides data on: GPS Time, GPS Date, GPS Latitude, GPS Longitude, Direction, GPS Quality, and GPS Altitude.

The database consists of 19 text files (a file for each vehicle) where measurement data are collected for the time period under consideration (June to October 2009). Each text row contains 19 parameters for every second. The total number of rows for Slovenia is $6,825,444$.

We are aware that the collected data are not the latest and it may not be entirely representative today; however, that does not affect the methodology of data post processing. The presented methodology is suitable for any available trip database, time and/or space independently.

The obtained data form the basis for the development of the Ljubljana urban driving cycle. Prior to the driving cycle calculation, the data need to be pre-processed as discussed later on.

\subsubsection{Data post processing}

Parameters selected to be used for post processing are date, time, counter, OBD velocity, longitude and latitude; the latter two have to be transformed to Gauss - Krüger coordinate system. Counter, date and time allow combining data into a set of trips. Accelerations and decelerations that are crucial for the driving cycle development were not directly measured; however, the collected data enable their precise calculation.

The data in the aforementioned research were collected throughout Slovenia. For the purpose of the presented research, where driving cycle for Ljubljana urban area is to be developed, the database has to contain only those trips that occurred in the Ljubljana urban area (limited by the motorway ring-road around the city). The surface of the urban area is approximately $55 \mathrm{~km}^{2}$. To limit the data collected all over Slovenia to Ljubljana urban area, Geographic Information Systems were used. The data were imported in suitable software (Esri ArcMap 10.1), where they were displayed as points in vector data layer. By using additional tools ET Geo Wizards for ArcGis, points were connected to form lines, using date, time and counter data. Consequently, individual trip data were obtained. In the next step, these data were further limited to the Ljubljana urban area, creating an appropriate database to be used for the driving cycle development. Out of a total of $6,825,444$ collected records, GIS analysis identified 416,471 records as the data within the analysed area, that represent the database for further procedures. Figure 1 presents the Ljubljana urban area and the paths within the area on the vector data layer. 
P. Lipar, I. Strnad, M. Česnik, T. Maher: Development of Urban Driving Cycle with GPS Data Post Processing

Table 1 - Fleet structure and driver information

\begin{tabular}{|c|c|c|c|c|c|c|c|}
\hline $\begin{array}{l}\text { Driver's } \\
\text { age }\end{array}$ & Vehicle & Fuel type & $\begin{array}{l}\text { Engine dis- } \\
\text { placements }\end{array}$ & $\begin{array}{l}\text { Engine } \\
\text { power }\end{array}$ & Trip purpose and frequency & $\mathrm{Km} /$ year & $\begin{array}{l}\text { Vehicle } \\
\text { age }\end{array}$ \\
\hline 38 & Ford Focus & Petrol & $1,600 \mathrm{ccm}$ & $74 \mathrm{~kW}$ & $\begin{array}{l}\text { commuter, distance } 10 \mathrm{~km} \\
\text { one way + occasional use }\end{array}$ & 10,000 & 6 \\
\hline 35 & Peugeot 207 & Petrol & $1,360 \mathrm{ccm}$ & $65 \mathrm{~kW}$ & $\begin{array}{l}\text { commuter, distance } 3 \mathrm{~km} \\
\text { one way + occasional use }\end{array}$ & 10,000 & 2 \\
\hline 42 & Honda Accord & Diesel & $2,204 \mathrm{ccm}$ & $103 \mathrm{~kW}$ & $\begin{array}{l}\text { ocassionally at afternoons } \\
\text { and weekends }\end{array}$ & 9,000 & 4 \\
\hline 26 & $\begin{array}{c}\text { Renault Mégane } \\
\text { Break }\end{array}$ & Petrol & $1,596 \mathrm{ccm}$ & 79 kW & $\begin{array}{l}\text { commuter, distance } 42 \mathrm{~km} \\
\text { one way + occasional use }\end{array}$ & 25,000 & 7 \\
\hline 55 & Hyundai Santa Fe & Diesel & $2,200 \mathrm{ccm}$ & 109 kW & $\begin{array}{l}\text { commuter, distance } 5 \mathrm{~km} \text { one } \\
\text { way + occasional use }\end{array}$ & 23,000 & 3 \\
\hline 29 & $\begin{array}{c}\text { Renault Mégane } \\
\text { Grandtour }\end{array}$ & Petrol & $1,600 \mathrm{ccm}$ & $83 \mathrm{~kW}$ & $\begin{array}{l}\text { commuter, distance } 8 \mathrm{~km} \\
\text { one way + occasional use }\end{array}$ & 15,000 & 5 \\
\hline 43 & VW Passat & Diesel & $2,000 \mathrm{ccm}$ & $103 \mathrm{~kW}$ & $\begin{array}{l}\text { commuter, distance } 8 \mathrm{~km} \\
\text { one way + occasional use }\end{array}$ & 25,000 & 3 \\
\hline 35 & Mitsubishi Colt & Petrol & $1,332 \mathrm{ccm}$ & $70 \mathrm{~kW}$ & $\begin{array}{l}\text { commuter, distance } 25 \mathrm{~km} \\
\text { one way + occasional use }\end{array}$ & 15,000 & 4 \\
\hline 42 & Renault Clio III & Petrol & $1,149 \mathrm{ccm}$ & $55 \mathrm{~kW}$ & $\begin{array}{l}\text { commuter, distance } 4 \mathrm{~km} \\
\text { one way + occasional use }\end{array}$ & 4,500 & 4 \\
\hline 43 & Renault Modus & Diesel & $1,500 \mathrm{ccm}$ & $63 \mathrm{~kW}$ & $\begin{array}{l}\text { commuter, distance } 30 \mathrm{~km} \\
\text { one way + occasional use }\end{array}$ & 25,000 & 1 \\
\hline 32 & Ford Focus & Diesel & $1,800 \mathrm{ccm}$ & $74 \mathrm{~kW}$ & $\begin{array}{l}\text { commuter, distance } 30 \mathrm{~km} \\
\text { one way + occasional use }\end{array}$ & 40,000 & 5 \\
\hline 28 & Hyundai i30 & Petrol & $1,396 \mathrm{ccm}$ & $80.2 \mathrm{~kW}$ & $\begin{array}{l}\text { commuter, distance } 15 \mathrm{~km} \\
\text { one way + occasional use }\end{array}$ & 20,000 & 1 \\
\hline 57 & Ford Focus SW & Petrol & $1,600 \mathrm{ccm}$ & 74 kW & $\begin{array}{l}\text { commuter, distance } 1 \mathrm{~km} \\
\text { one way + occasional use }\end{array}$ & 20,000 & 6 \\
\hline 40 & Opel Zafira & Diesel & $2,000 \mathrm{ccm}$ & $75 \mathrm{~kW}$ & $\begin{array}{l}\text { commuter, distance } 5 \mathrm{~km} \\
\text { one way + occasional use }\end{array}$ & 15,000 & 5 \\
\hline 55 & BMW 320D & Diesel & $2,000 \mathrm{ccm}$ & $119 \mathrm{~kW}$ & $\begin{array}{l}\text { commuter, distance } 60 \mathrm{~km} \\
\text { one way + occasional use }\end{array}$ & 40,000 & 2 \\
\hline 38 & Jaguar X type & Diesel & $2,200 \mathrm{ccm}$ & $113 \mathrm{~kW}$ & $\begin{array}{l}\text { commuter, distance } 15 \mathrm{~km} \\
\text { one way + occasional use }\end{array}$ & 24,000 & 1 \\
\hline 35 & VW Passat & Diesel & $1,900 \mathrm{ccm}$ & 96 kW & $\begin{array}{l}\text { commuter, distance } 25 \mathrm{~km} \\
\text { one way + occasional use }\end{array}$ & 21,000 & 6 \\
\hline 29 & Renault Mégane & Diesel & $1,461 \mathrm{ccm}$ & $60 \mathrm{~kW}$ & $\begin{array}{l}\text { commuter, distance } 4 \mathrm{~km} \\
\text { one way + occasional use }\end{array}$ & 24,000 & 5 \\
\hline 60 & Opel Zafira & Diesel & $1,910 \mathrm{ccm}$ & $74 \mathrm{~kW}$ & $\begin{array}{l}\text { commuter, distance } 80 \mathrm{~km} \\
\text { one way + occasional use }\end{array}$ & 55,000 & 2 \\
\hline
\end{tabular}

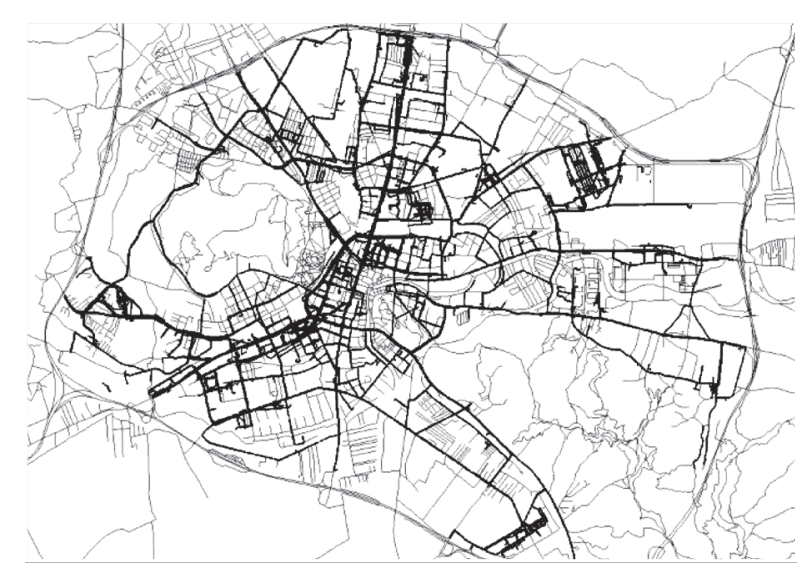

Figure 1 - Paths within Ljubljana urban area on vector data layer

\subsubsection{Driving characteristics}

Speed-acceleration frequency distribution (SAFD) was obtained by using the analysis of the post-processed data and converted to a probability distribution (SAPD) for Ljubljana urban area. SAPD gives probability that the trip is located within a particular velocity and acceleration range, which gives the information about the percentage of total time spent in each driving style. SAPD is shown in Figure 2 that clearly shows a high percentage of time, where vehicles are stopped. These results suggest dense traffic with several long stops, which is indicated as a spike. It can also be noted that the observed speeds are consistent to the speed limits in the area, which are within the range of 30 to $70 \mathrm{~km} / \mathrm{h}$. 


\subsubsection{Target parameters}

From the obtained database, the following driving parameters were calculated: average speed $\left(\mathrm{V}_{\text {avg }}\right)$, time periods in acceleration (\%Acc), in deceleration (\%Dec), at cruise (\%Cruise) and at idle (\%ldle), number of stops per kilometre of driving (Stop/km), average acceleration $\left(\mathrm{Acc}_{\mathrm{avg}}\right)$ and deceleration $\left(\mathrm{Dec}_{\mathrm{avg}}\right)$ and positive kinetic energy (PKE) (Table 2). These parameters have been accepted as indicators of the actual on-road driving situations [3]

Table 2 - Target parameters from collected speed time data

\begin{tabular}{||c|c||}
\hline Target parameter & 22.42 \\
\hline \hline $\mathrm{V}_{\text {avg }}(\mathrm{km} / \mathrm{h})$ & 0.82 \\
\hline Acc $_{\text {avg }}(\mathrm{m} / \mathrm{s} 2)$ & -0.75 \\
\hline $\operatorname{Dec}_{\text {avg }}(\mathrm{m} / \mathrm{s} 2)$ & 22.61 \\
\hline$\%$ Idle $(\%)$ & 22.45 \\
\hline$\%$ Cruise $(\%)$ & 27.04 \\
\hline$\%$ Acc $(\%)$ & 27.90 \\
\hline$\%$ Dec $(\%)$ & 1.97 \\
\hline Stop $/ \mathrm{km}$ & 0.461 \\
\hline PKE $\left(\mathrm{m} / \mathrm{s}^{2}\right)$ & \\
\hline
\end{tabular}

and are called target parameters [6]. Within the presented research they are used as a set of criteria that describe quality of fit of the finally selected driving cycle, when compared to the trip data.

\subsection{Microtrip determination}

Based on the available data, a suitable construction method to develop a driving cycle has to be selected. Despite the fact that the data collection method was not predefined and the data were not collected with the purpose of developing a driving cycle, the appropriate data post processing enabled exact derivation of microtrips within the Ljubljana urban area from the post-processed second-by-second driving data. A microtrip is defined as the sequences of driving data between successive stops in a trip [21, 22].

As the most important variables, on which the selection of the cycle development method will be based, the speed and acceleration are considered. These two variables provide a measure of the load on the engine, which is an important variable associated with exhaust emissions. We chose the approach, where microtrips are selected from the database and

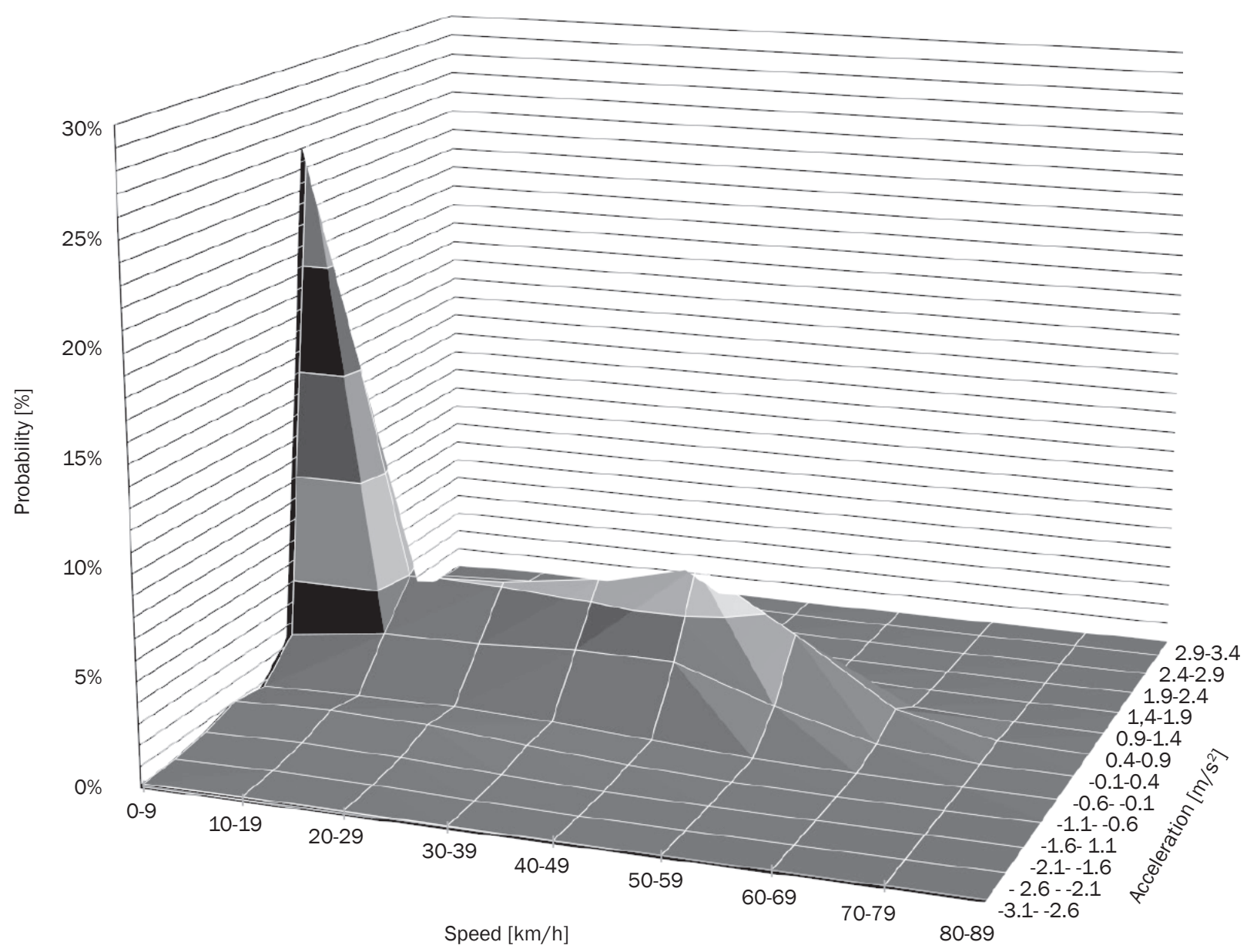

Figure 2 - Probability distribution of velocity and acceleration 
Table 3 - Microtrips classification

\begin{tabular}{||l|c|c|c|c|c|c|c||}
\hline \multirow{2}{*}{} & \multicolumn{7}{c|}{ Speed interval $(\mathrm{km} / \mathrm{h})$} \\
\cline { 2 - 9 } & $\mathrm{V}=0$ & $0<\mathrm{V} \leq 10$ & $10<\mathrm{V} \leq 20$ & $20<\mathrm{V} \leq 30$ & $30<\mathrm{V} \leq 40$ & $\mathrm{~V}>40$ & $\Sigma$ \\
\hline \hline Number of microtrips & - & 383 & 1,562 & 2,032 & 1,567 & 567 & 6,111 \\
\hline \% of microtrips & - & 6.27 & 25.56 & 33.25 & 25.64 & 9.28 & 100 \\
\hline Seconds within interval & 109,359 & 56,458 & 74,961 & 71,175 & 69,601 & 102,010 & 483,564 \\
\hline$\%$ of seconds within interval & 22.61 & 11.68 & 15.50 & 14.72 & 14.39 & 21.10 & 100 \\
\hline
\end{tabular}

connected in a series to form a driving cycle in such a way that speed-acceleration frequency distribution of the driving cycle is matched to the frequency distribution from the collected speed-time data. Using this approach ensures that emission levels, determined from the obtained driving cycle, will be strictly related to actual emissions caused by road traffic.

\subsubsection{Microtrip determination}

The post processed data need to be divided into a set of microtrips, which are later on used to form the driving cycle. The data were divided into a total of 6,111 microtrips that are separated with successive stops (zero speed) and numbered. Driving parameters were calculated for each microtrip; this enabled comparison of the driving cycle formed out of microtrips to target parameters, calculated from the collected data. Microtrips were classified and grouped into five speed intervals according to the average speed. The number of microtrips and the duration within each speed interval are presented in Table 3.

The majority of microtrips in Ljubljana urban area (84.45\%) are within the speed range from 10 to 40 $\mathrm{km} / \mathrm{h}$. Nevertheless, the vehicles spend more than one third of the total time within speed ranges less than $10 \mathrm{~km} / \mathrm{h}$. This indicates that the traffic in the Ljubljana urban area is dense with several long stops, especially during the peak period. However, it can be also noted that vehicles spend over one third of the total time within speed intervals of over $30 \mathrm{~km} / \mathrm{h}$, which corresponds to off-peak periods and weekends.

\subsubsection{Construction procedure}

The selected procedure uses the vector form of describing speed-acceleration frequency distribution. The combination of microtrips in the series was performed, based on minimizing the difference between cycle vector $C$ representing driving in the candidate cycle and target vector $T$ representing driving in the activity database as proposed by Fincher et al. [23]. While target vector $T$ is fixed, the resulting cycle vector $C$ is the resultant vector in the process of searching micro-trips $M_{i}$ and adding them to the first micro-trip $M_{1}$ (Figure 3) which is selected as the closest to the target vector $T$. As microtrips are added to create a resulting driving cycle $C$, the difference $T-C$ is getting smaller, although it can slightly increase at some point during the process. The iteration process finished when convergence of the process was noticed for the selected cycle duration.

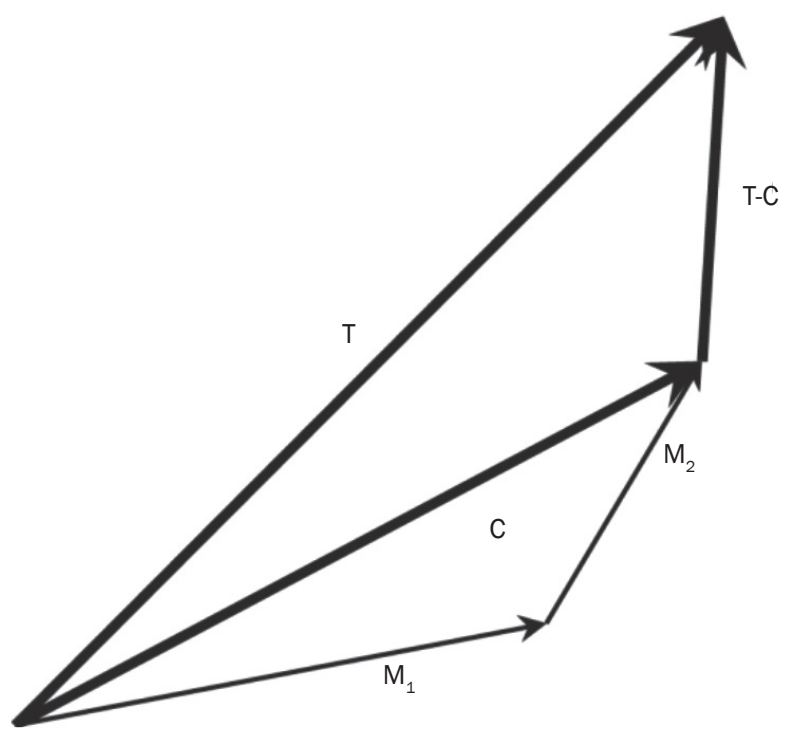

Figure 3 - Vector description of comparing target and cycle activity [23]

The acceptable duration of the new developed driving cycle has to be determined in advance. We estimate that approximately a 25-minute long cycle would be the most appropriate in order to account for sufficient number of microtrips that reflect the actual driving patterns, but not too long to be unpractical for testing on a dynamometer.

The vectors above are graphical representations of the cumulative frequency distributions. Speed-acceleration frequency distributions can be used as description of every microtrip (and summed to cycle which they form) by using a matrix form to convert the continuous values of speed and acceleration into frequency distributions. The cumulative frequency distributions can then be easily calculated by summing the number of observations that fall below the current bin for each of the two variables, i.e. sequentially across each row and each column. For the purpose of comparison between the cycle activity matrix and the target activity matrix of the database, the elements of cumulative frequency distributions for both cases need to be normalized to account for the total number of 
Table 4 - Normalized cumulative frequency distributions - target activity matrix

\begin{tabular}{||c|c|c|c|c|c|c|c|c|c|c||}
\hline & $\mathrm{A}$ & $\mathrm{B}$ & $\mathrm{C}$ & $\mathrm{D}$ & $\mathrm{E}$ & $\mathrm{F}$ & $\mathrm{G}$ & $\mathrm{H}$ & $\mathrm{I}$ & $\mathrm{J}$ \\
\hline \hline 1 & 0.000 & 0.014 & 0.014 & 0.014 & 0.014 & 0.014 & 0.014 & 0.054 & 0.054 & 0.054 \\
\hline 2 & 0.027 & 0.041 & 0.041 & 0.041 & 0.041 & 0.041 & 0.041 & 0.081 & 0.081 & 0.081 \\
\hline 3 & 0.027 & 0.068 & 0.068 & 0.068 & 0.108 & 0.108 & 0.108 & 0.149 & 0.149 & 0.203 \\
\hline 4 & 0.027 & 0.068 & 0.068 & 0.135 & 0.176 & 0.176 & 0.176 & 0.216 & 0.216 & 0.270 \\
\hline 5 & 0.027 & 0.122 & 0.122 & 0.189 & 0.270 & 0.270 & 0.270 & 0.378 & 0.419 & 0.473 \\
\hline 6 & 0.027 & 0.176 & 0.176 & 0.243 & 0.324 & 0.378 & 0.419 & 0.527 & 0.568 & 0.622 \\
\hline 7 & 0.054 & 0.203 & 0.203 & 0.270 & 0.351 & 0.405 & 0.446 & 0.554 & 0.595 & 0.649 \\
\hline 8 & 0.054 & 0.203 & 0.351 & 0.351 & 0.432 & 0.486 & 0.527 & 0.635 & 0.797 & 0.851 \\
\hline 9 & 0.054 & 0.203 & 0.351 & 0.378 & 0.459 & 0.622 & 0.662 & 0.770 & 0.932 & 0.986 \\
\hline 10 & 0.068 & 0.216 & 0.365 & 0.392 & 0.473 & 0.635 & 0.676 & 0.784 & 0.946 & 1.000 \\
\hline
\end{tabular}

Table 5 - Normalized cumulative frequency distributions - chosen driving cycle activity matrix

\begin{tabular}{||c|c|c|c|c|c|c|c|c|c|c||}
\hline & $\mathrm{A}$ & $\mathrm{B}$ & $\mathrm{C}$ & $\mathrm{D}$ & $\mathrm{E}$ & $\mathrm{F}$ & $\mathrm{G}$ & $\mathrm{H}$ & $\mathrm{I}$ & $\mathrm{J}$ \\
\hline \hline 1 & 0.000 & 0.018 & 0.018 & 0.018 & 0.018 & 0.018 & 0.018 & 0.073 & 0.073 & 0.073 \\
\hline 2 & 0.000 & 0.018 & 0.018 & 0.018 & 0.018 & 0.018 & 0.018 & 0.073 & 0.073 & 0.073 \\
\hline 3 & 0.091 & 0.109 & 0.164 & 0.164 & 0.236 & 0.236 & 0.291 & 0.345 & 0.345 & 0.345 \\
\hline 4 & 0.091 & 0.109 & 0.164 & 0.164 & 0.236 & 0.236 & 0.291 & 0.345 & 0.345 & 0.345 \\
\hline 5 & 0.091 & 0.109 & 0.218 & 0.218 & 0.291 & 0.364 & 0.418 & 0.473 & 0.564 & 0.564 \\
\hline 6 & 0.145 & 0.164 & 0.273 & 0.273 & 0.345 & 0.418 & 0.473 & 0.527 & 0.618 & 0.618 \\
\hline 7 & 0.145 & 0.164 & 0.273 & 0.273 & 0.345 & 0.455 & 0.509 & 0.564 & 0.655 & 0.655 \\
\hline 8 & 0.145 & 0.164 & 0.364 & 0.364 & 0.436 & 0.545 & 0.600 & 0.655 & 0.745 & 0.745 \\
\hline 9 & 0.218 & 0.236 & 0.436 & 0.436 & 0.564 & 0.673 & 0.727 & 0.782 & 0.945 & 0.945 \\
\hline 10 & 0.218 & 0.236 & 0.436 & 0.436 & 0.564 & 0.673 & 0.782 & 0.836 & 1.000 & 1.000 \\
\hline \hline
\end{tabular}

observations. The normalized frequencies for target and the chosen driving cycle data are shown in Tables 4 and 5. After calculation of the sum of the squared differences we get a value which presents the square of length of the vector $\mathrm{T}-\mathrm{C}$, which is to be minimized in the iteration process. The procedure is repeated until the convergence of the process is noticed for the chosen cycle duration. For the final chosen driving cycle, the sum of squared differences equals 0.538 .

Thus determined driving cycle consists of a typical set of microtrips. The chosen driving cycle is finally written in a second format using time-space relations.

\section{RESULTS}

\subsection{Ljubljana urban driving cycle LJURBAN}

By using the above-described approach, the Ljubljana urban driving cycle, called LJURBAN, was developed. The driving cycle duration is 1,587 seconds with approximate travelling speed of $22.5 \mathrm{~km} / \mathrm{h}$ at the length of $10.19 \mathrm{~km}$ and presented in Figure 4.

Table 6 provides comparison of target parameters between the actual trips in the database and the developed driving cycle LJURBAN.

Table 6 - Comparison between collected speed time data and driving cycle LJURBAN

\begin{tabular}{||c|c|c|c||}
\hline $\begin{array}{c}\text { Target } \\
\text { parameter }\end{array}$ & Database & LURBAN & Difference \% \\
\hline \hline $\mathrm{V}_{\text {avg }}(\mathrm{km} / \mathrm{h})$ & 22.42 & 22.50 & 0.36 \\
\hline Acc $_{\text {avg }}(\mathrm{m} / \mathrm{s} 2)$ & 0.82 & 0.83 & 1.2 \\
\hline Dec $_{\text {avg }}(\mathrm{m} / \mathrm{s} 2)$ & -0.75 & -0.77 & 2.6 \\
\hline$\%$ Idle $(\%)$ & 22.61 & 22.50 & 0.49 \\
\hline$\%$ Cruise $(\%)$ & 22.45 & 21.55 & 4 \\
\hline$\%$ Acc $(\%)$ & 27.04 & 27.73 & 2.49 \\
\hline$\%$ Dec $(\%)$ & 27.90 & 28.23 & 1.17 \\
\hline Stop $/ \mathrm{km}$ & 1.97 & 2.08 & 5.3 \\
\hline PKE $\left(\mathrm{m} / \mathrm{s}^{2}\right)$ & 0.461 & 0.510 & 9.6 \\
\hline
\end{tabular}




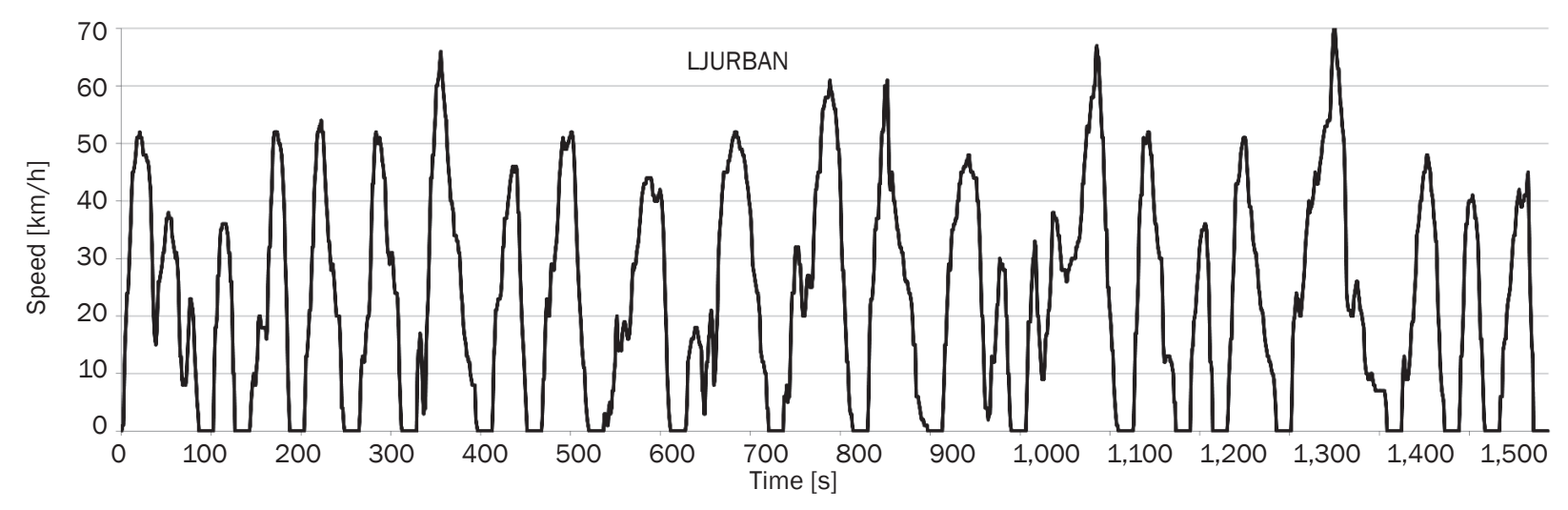

Figure 4 - Urban driving cycle of Ljubljana (LURBAN)

Differences in parameters are small and do not exceed $5 \%$, except for the number of stops per kilometre and positive kinetic energy. Comparison between Figures 2 and 5 shows minimal differences in speed-acceleration probability distribution. The two graphs are very similar; differences are the largest in the speed range of 20 to $50 \mathrm{~km} / \mathrm{h}$ (2.1\% total) and in acceleration range -0.1 to $0.9 \mathrm{~m} / \mathrm{s} 2(1.73 \%$ total). Since the probability distribution of driving cycle LJURBAN fits the actual collected data well, the driving cycle LJURBAN clearly shows representative driving behaviour.

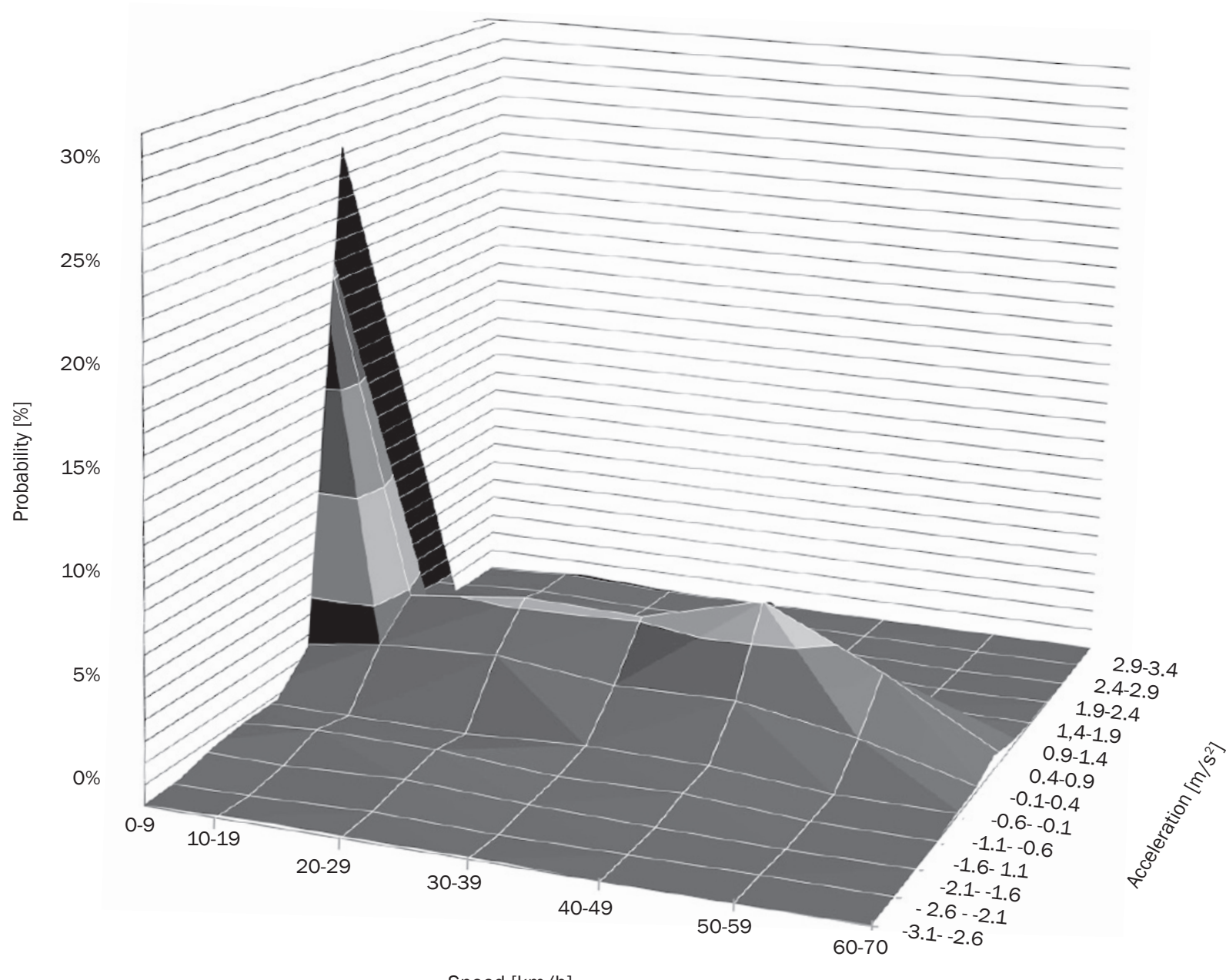

Figure 5- Probability distribution speed -acceleration of driving cycle LURBAN 


\subsection{Comparison of standard driving cycles to LJURBAN}

The LJURBAN driving cycle is compared to the so called standard driving cycles to emphasize the need for area-specific driving cycle. Four standard driving cycles were chosen for the comparison with LJURBAN; namely, NEDC, Artemis Urban, FTP 75, NYCC (an overview presented in [1], 24]).

Table 7 presents the comparison among driving cycles. Cycles vary in the total distance and time, but also in the driving pattern, which can be observed by comparing the proportions of time spent in each driving pattern (cruise, accelerating, decelerating, and standing). Most of the parameter values lie somewhere between the values for other driving cycles. However, the average positive acceleration is by far the highest for LURBAN and the average negative deceleration is the smallest of them all, indicating a driving pattern with several oscillations in speed and several stops and starts, which is also supported by a high number of accelerations and stops. The standing time is also the longest for LUURBAN, although the percentage of time spent standing is higher for NYCC (this difference arises because of the absolute difference in total time).

\subsection{Emission simulation}

Driving cycle LUURBAN was used to quantify the emissions of vehicles using ADVISOR (Advanced Vehicle Simulator) software, developed by the National Renewable Energy Laboratory. The most common vehicle configuration was first selected (conventional, mid-size vehicle with $89 \mathrm{~kW}$, front-wheel drive, manual transmission and constant rolling resistance coefficient) appropriate for daily use in the urban area.

Multiple cycles were simulated in order to compare the evaluated emissions in dependence on the chosen driving cycle; namely ECE + EUDC, NEDC, FTP 72, Japan 10 - 15 Mode, LA92 and INRETS (an overview presented in [24]). The program models emissions of carbon oxide (CO), nitrogen oxide (NOx) and hydrocarbons (all in $\mathrm{g} / \mathrm{km}$ ) and fuel consumption (l/100 km). The results are shown on Figures 7-9.

Figure 6 shows the comparison of emission levels for LJURBAN and other driving cycles. High emission levels can be observed for driving cycle Japan 10 -15 that consists of parts with high accelerations and decelerations. Similar but slightly lower emission and levels can be observed for driving Cycle LUURBAN, showing that particular driving pattern with high frequency of accelerations and decelerations affects emissions and especially fuel consumption levels.

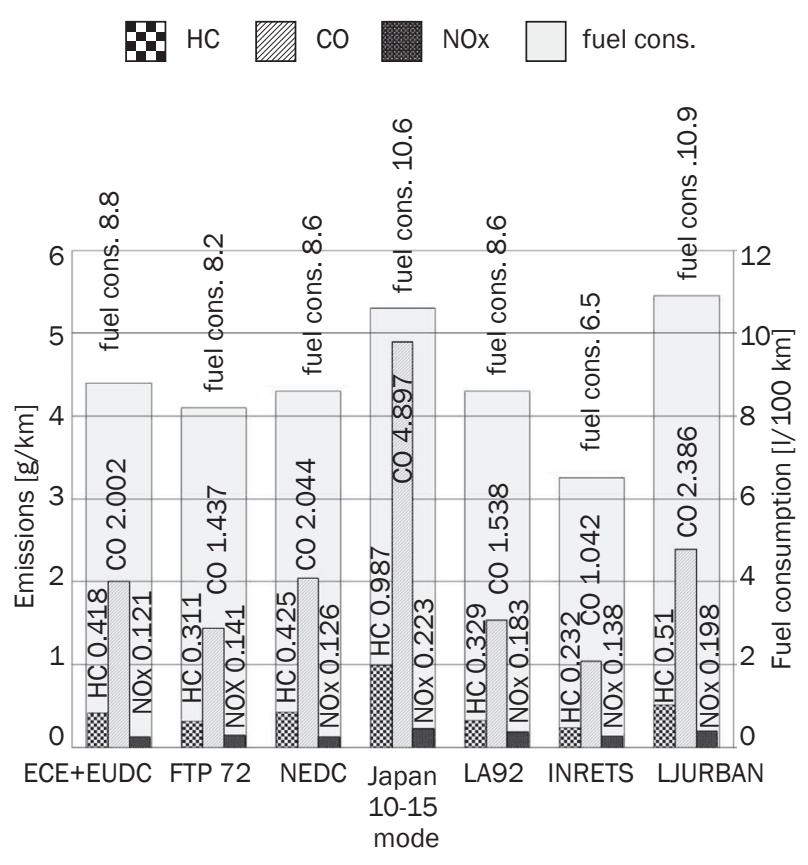

Figure 6 - Comparison of emission levels and consumption for LUURBAN and other driving cycles

\section{DISCUSSION}

The presented research is based on the available database of trips that were not predefined and as such, they reflect the actual traveller's needs and traffic flow conditions.

Instead of the usual procedure, where the data collection method is carefully designed in order to obtain the data that best suite the chosen cycle development method, the appropriate method had to be selected with respect to the available large database. The data had to be post processed to select the representative data that describe a typical driving pattern in a certain urban area. All the excess data that could contain unrepresentative driving pattern should be excluded. The introduction of GIS technology into a driving cycle development was unique and presents a new approach in this area.

The probability distribution obtained with the above described methodology fits the actual collected data well; therefore, the cycle LUURBAN clearly shows representative driving pattern. Due to not having predetermined paths regarding actual travellers' needs and a wide range of different travellers' characteristics, we can clearly conclude that the developed data and consequently, the developed driving cycle describe realistic citizen behaviour.

The results of the comparison to other already known driving cycles discussed in the previous chapter clearly show that the developed driving cycle LUURBAN differentiates significantly from all other widely used 
Table 7 - Driving cycles comparison

\begin{tabular}{|c|c|c|c|c|c|c|c|c|c|}
\hline \multirow[b]{2}{*}{ Parameter } & \multicolumn{9}{|c|}{ Driving cycle } \\
\hline & 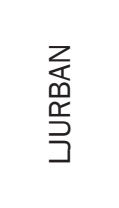 & $\begin{array}{l}\text { 号 } \\
\text { 岁 }\end{array}$ & 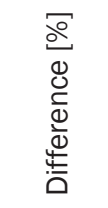 & 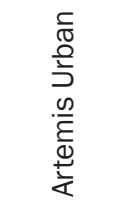 & 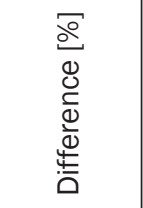 & $\begin{array}{l}\stackrel{0}{\wedge} \\
\text { 是 }\end{array}$ & 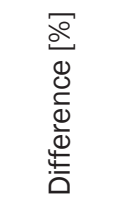 & $\begin{array}{l}\text { O } \\
\Sigma\end{array}$ & 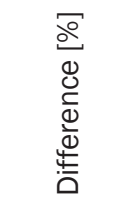 \\
\hline Total distance $[\mathrm{km}]$ & 10.19 & 11.02 & 8.15 & 4.87 & 52.21 & 17.79 & 74.58 & 1.9 & 81.35 \\
\hline Total time $[\mathrm{s}]$ & 1,587 & 1,180 & 25.65 & 993 & 37.43 & 1,874 & 18.08 & 598 & 62.32 \\
\hline Driving time [s] & 1,230 & 939 & 23.66 & 787 & 36.02 & 1,633 & 32.76 & 412 & 66.50 \\
\hline Drive time [s] & 342 & 458 & 33.92 & 95 & 72.22 & 376 & 9.94 & 61 & 82.16 \\
\hline $\begin{array}{l}\text { Drive time spent } \\
\text { accelerating [s] }\end{array}$ & 440 & 278 & 36.82 & 357 & 18.86 & 683 & 55.23 & 176 & 60.00 \\
\hline $\begin{array}{l}\text { Drive time spent } \\
\text { decelerating [s] }\end{array}$ & 448 & 204 & 54.46 & 335 & 25.22 & 574 & 28.13 & 175 & 60.94 \\
\hline Standing time [s] & 357 & 241 & 32.49 & 206 & 42.3 & 241 & 32.49 & 186 & 47.90 \\
\hline$\%$ of time driving & 77.5 & 79.58 & 2.68 & 79.25 & 2.26 & 87.14 & 12.44 & 68.9 & 11.10 \\
\hline$\%$ of cruising & 21.55 & 38.81 & 80.09 & 9.57 & 55.59 & 20.06 & 6.91 & 10.2 & 52.67 \\
\hline $\begin{array}{l}\% \text { of time } \\
\text { accelerating }\end{array}$ & 27.73 & 23.56 & 15.04 & 35.95 & 29.64 & 36.45 & 31.45 & 29.43 & 6.13 \\
\hline $\begin{array}{l}\% \text { of time } \\
\text { decelerating }\end{array}$ & 28.23 & 17.29 & 38.75 & 33.74 & 19.52 & 30.63 & 8.5 & 29.26 & 3.65 \\
\hline$\%$ of time standing & 22.5 & 20.42 & 9.24 & 20.75 & 7.78 & 12.86 & 42.84 & 31.1 & 38.22 \\
\hline $\begin{array}{l}\text { Average speed } \\
{[\mathrm{km} / \mathrm{h}]}\end{array}$ & 29 & 42.2 & 45.52 & 22.29 & 23.14 & 34.2 & 17.93 & 16.63 & 42.66 \\
\hline $\begin{array}{l}\text { Average driving } \\
\text { speed }[\mathrm{km} / \mathrm{h}]\end{array}$ & 22.5 & 33.6 & 49.33 & 17.7 & 21.33 & 39.21 & 74.27 & 11.5 & 48.89 \\
\hline $\begin{array}{l}\text { Std. deviation of } \\
\text { speed }[\mathrm{km} / \mathrm{h}]\end{array}$ & 18.57 & 28.91 & 55.68 & 16.07 & 13.46 & 37.49 & 26.6 & 12.23 & 34.14 \\
\hline $\begin{array}{l}\text { Speed: } 75 \mathrm{th}-25 \mathrm{th} \\
\text { percentile }[\mathrm{km} / \mathrm{h}]\end{array}$ & 35 & 46.7 & 33.43 & 32.47 & 7.23 & 37.49 & 7.11 & 20.15 & 42.43 \\
\hline $\begin{array}{l}\text { Maximum speed } \\
{[\mathrm{km} / \mathrm{h}]}\end{array}$ & 70 & 120.09 & 71.56 & 57.32 & 18.11 & 91.09 & 30.13 & 44.45 & 36.50 \\
\hline $\begin{array}{l}\text { Average positive } \\
\text { acc. }\left[\mathrm{m} / \mathrm{s}^{2}\right]\end{array}$ & 0.83 & 0.528 & 36.39 & 0.531 & 36.02 & 0.42 & 49.4 & 0.466 & 43.86 \\
\hline $\begin{array}{l}\text { Average negative } \\
\text { acc. }\left[\mathrm{m} / \mathrm{s}^{2}\right]\end{array}$ & -0.766 & -0.719 & 6.14 & -0.571 & 25.46 & -0.457 & 40.34 & -0.48 & 37.34 \\
\hline $\begin{array}{l}\text { Std. deviation of } \\
\text { acc. }\left[\mathrm{m} / \mathrm{s}^{2}\right]\end{array}$ & 0.598 & 0.476 & 20.4 & 0.732 & 22.41 & 0.629 & 5.18 & 0.652 & 9.03 \\
\hline $\begin{array}{l}\text { Std. deviation of } \\
\text { positive acc. }\left[\mathrm{m} / \mathrm{s}^{2}\right]\end{array}$ & 0.611 & 0.243 & 60.23 & 0.454 & 25.7 & 0.423 & 30.77 & 0.448 & 26.68 \\
\hline $\begin{array}{l}\text { Number of } \\
\text { accelerations }\end{array}$ & 151 & 31 & 79.47 & 48 & 68.21 & 61 & 59.6 & 22 & 85.43 \\
\hline $\begin{array}{l}\text { Accelerations } \\
\text { per km }\end{array}$ & 14.82 & 2.814 & 81.01 & 9.849 & 33.54 & 3.43 & 76.86 & 11.562 & 21.98 \\
\hline Number of stops & 21 & 14 & 33.33 & 14 & 33.33 & 16 & 23.81 & 7 & 66.67 \\
\hline Stops per km & 2.06 & 1.27 & 38.35 & 2.87 & 39.32 & 0.9 & 56.31 & 3.68 & 78.64 \\
\hline $\begin{array}{l}\text { Average distance } \\
\text { between stops }\end{array}$ & 485.19 & 786.9 & 62.18 & 348.12 & 28.25 & $1,111.66$ & 129.12 & 271.82 & 43.98 \\
\hline $\begin{array}{l}\text { Positive kinetic } \\
\text { energy }\left[\mathrm{m} / \mathrm{s}^{2}\right]\end{array}$ & 0.51 & 0.224 & 56.08 & 7.139 & $12,999.8$ & 0.348 & 31.76 & 6.568 & $1,187.84$ \\
\hline
\end{tabular}




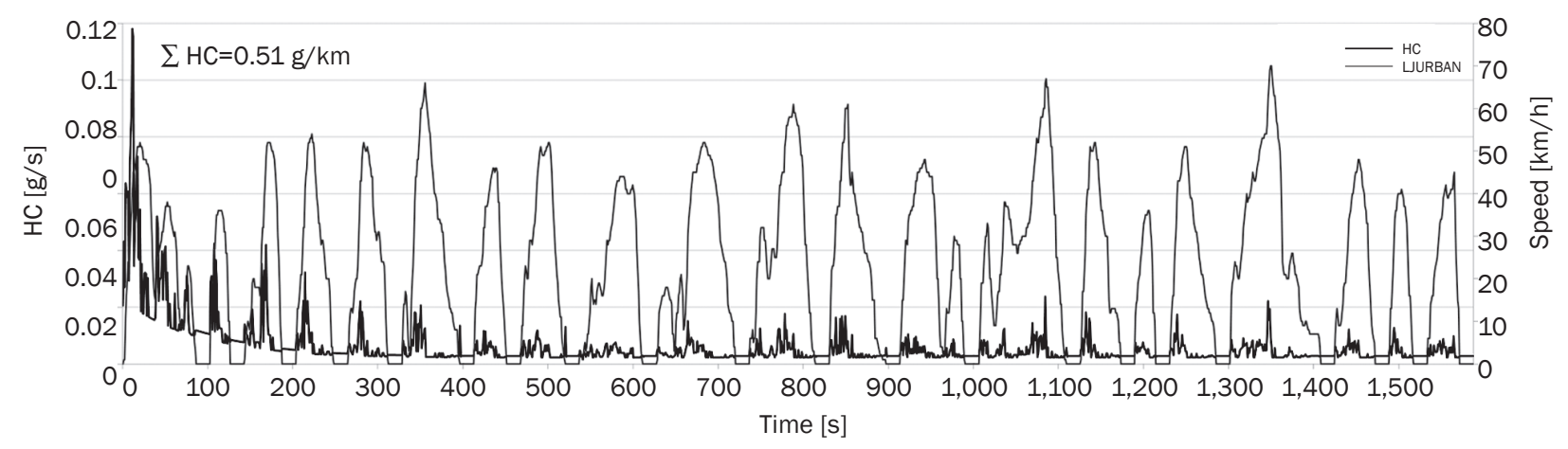

Figure 7 - HC emissions with LUURBAN

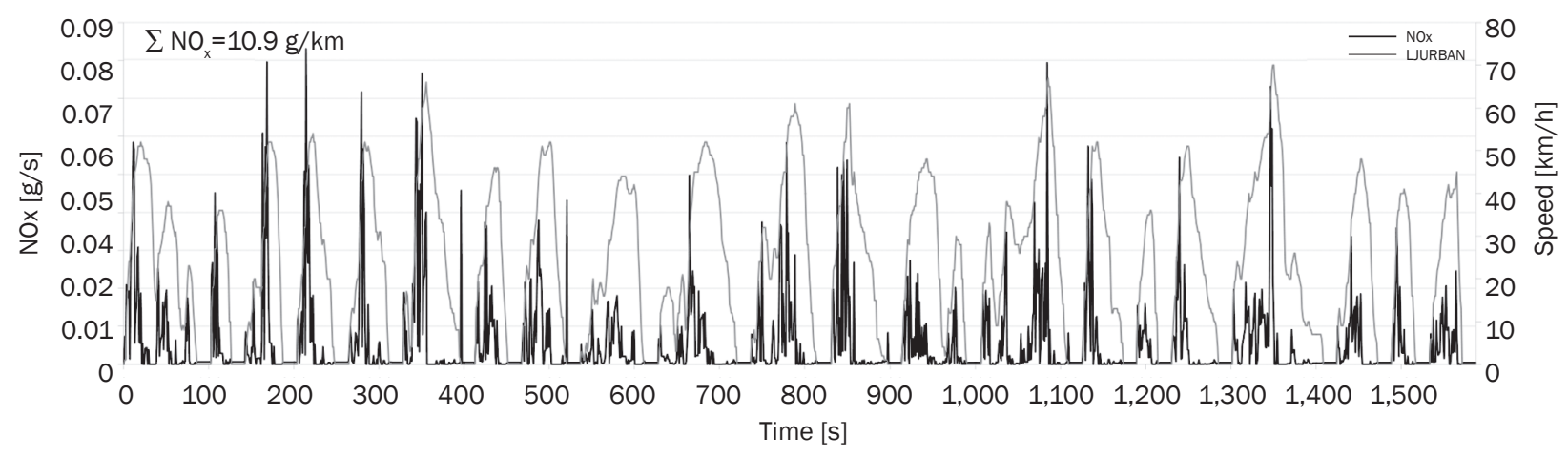

Figure 8 - NOx emissions with LUURBAN

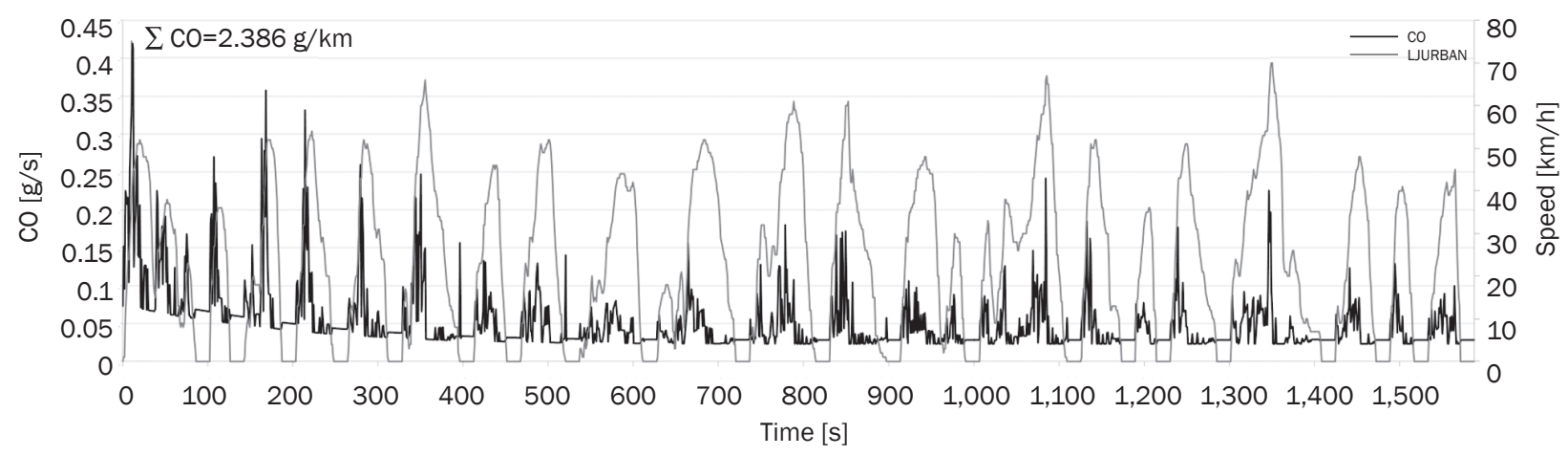

Figure 9 - CO emissions with LUURBAN

driving cycles due to a specific driving pattern. The analysis that was carried out shows that the driving pattern in Ljubljana contains long standing times and several oscillations in speed, in terms of accelerating as well as decelerating with highly positive/negative acceleration. The specific driving pattern emphasizes that standard driving cycles cannot describe actual conditions in the area under consideration.

The specific driving pattern results in high emissions, a subject of growing concern owing to a vulnerable climate environment in Ljubljana. Developing a representative driving cycle and assessing the representative emission model is therefore the first step of emission awareness and its reduction.

\section{CONCLUSION}

Comparison of the target parameters of the developed driving cycle LUURAN to the database target parameters shows good fitting, meaning that the driving cycle LUURBAN describes the driving pattern well. The major challenge was to limit the raw database consisting of time and space independent trip records to the selected area, which we managed using Geographic Information Systems. It is important to notice that our database consists of large random sample of trip data, which is an important advantage of the described approach, when compared to the usual approach with predefined trips, since it guarantees a more representative sample. The developed LURBAN urban driving cycle clearly shows a specific driving pattern in the 
area. Driving in Ljubljana urban area is characterized by long standing times, several oscillations in speed in terms of accelerating, as well as decelerating with highly positive/negative acceleration. The specific driving pattern in Ljubljana urban area results in high fuel consumption and emissions that represent a major problem in the area.

In order to representatively describe the typical driving, the Ljubljana urban area requires its own driving cycle. It is clear that it is necessary to define the typical driving cycles for various urban areas, not only within EU but worldwide, since the driving pattern depends on the typical national driving specificities and temperament.

Since the presented GIS-based methodology is suitable for the driving cycle development based on large trip databases (time and/or space independent), the future research should be focused on evaluation of the presented methodology for other types of available floating car data. Data post processing of large floating car databases, provided by locating the vehicle via mobile phones or GPS over the entire road network, represents the future challenge of GIS-based driving cycle development.

\section{Dr. PETER LIPAR ${ }^{1}$}

E-mail: peter.lipar@fgg.uni-lj.si

IRENA STRNAD ${ }^{1}$

E-mail: irena.strnad@fgg.uni-lj.si

MARTIN ČESNIK ${ }^{1}$

E-mail: martin.cesnik@gmail.com

Dr. TOMAŽ MAHER ${ }^{1}$

E-mail: tomaz.maher@fgg.uni-lj.si

${ }^{1}$ Univerza v Ljubljani,

Fakulteta za gradbeništva in geodezijo

Jamova cesta 2, 1000 Ljubljana, Slovenija

\section{RAZVOJ VOZNEGA CIKLA URBANEGA OBMOČJA NA OSNOVI POSTPROCESIRANJA GPS PODATKOV}

\section{POVZETEK}

$\checkmark$ prispevku je predstavljena metodologija razvoja voznega cikla $v$ mestih na podlagi GIS tehnologije. Pristop se bistveno razlikuje od običajnih metod razvoja voznih ciklov, saj ne temelji na običajnem, vnaprej načrtovanem zbiranju podatkov, ampak temelji na velikem vzorcu podatkov, $k i$ so zbrani $v$ vozilih. Ti so naknadno obdelani z uporabo tehnologije geografskih informacijskih sistemov tako, da se iz množice podatkov izloči samo značilne in geografsko omejene potovalne podatke. Tako so bili podatki prilagojeni za opis tipične vožnje na urbanem območju Ljubljane. Izbrana metoda za določitev voznega cikla temelji na iskanju takšne kombinacije mikropoti, s katero dosežemo konvergenco razlik med dvema vektorjema, ki predstavljata vožnjo na osnovi generiranega cikla in vožnjo na osnovi baze podatkov. Glede na velik naključni vzorec dejanskih podatkov, omogoča tak pristop določitev bolj reprezentativnega voznega cikla kot prej uporabljene metode.

\section{KLUČNE BESEDE}

vozni cikel; mikropoti; vzorec vožnje; emisije izpustov; poraba goriva; frekvenčna porazdelitev;

\section{REFERENCES}

[1] André M. The ARTEMIS European driving cycles for measuring car pollutant emissions. Science of the Total Environment. 2004;334-335:73-84.

[2] Lin J, Niemeier DA. Regional driving characteristics, regional driving cycles. Transportation Research Part D: Transport and Environment. 2003;8(5):361-381.

[3] Hung WT, Tam KM, Lee CP, Chan LY, Cheung CS. Comparison of driving characteristics in cities of Pearl River Delta, China. Atmospheric Environment. 2005;39(4):615-625.

[4] Hung WT, Tong HY, Lee CP, Ha K, Pao LY. Development of a practical driving cycle construction methodology: A case study in Hong Kong. Transportation Research Part D: Transport and Environment. 2007;12(2): 115-128.

[5] Wang Q, Huo H, He K, Yao Z, Zhang Q. Characterization of vehicle driving patterns and development of driving cycles in Chinese cities. Transportation research part D: Transport and Environment. 2008;13(5):289-297.

[6] Tamsanya S, Chungpaibulpatana S, Limmeechokchai B. Development of a driving cycle for the measurement of fuel consumption and exhaust emissions of automobiles in Bangkok during peak periods. International Journal of Automotive Technology. 2009;10(2): 251-264

[7] Kamble SH, Mathew TV, Sharma GK. Development of real-world driving cycle: Case study of Pune, India. Transportation Research Part D: Transport and Environment. 2009;14(2):132-140.

[8] Ji C, Wang S, Zhang B, Liu X. Emissions performance of a hybrid hydrogen-gasoline engine-powered passenger car under the New European Driving Cycle. Fuel. 2013;106:873-875.

[9] Armas O, García-Contreras R, Ramos Á. Impact of alternative fuels on performance and pollutant emissions of a light duty engine tested under the new European driving cycle. Applied Energy. 2013;107:183-190.

[10] Bermúdez V, Luján JM, Ruiz S, Campos D, Linares WG. New European Driving Cycle assessment by means of particle size distributions in a light-duty diesel engine fuelled with different fuel formulations. Fuel. 2015;140:649-659.

[11] Karavalakis G, Tzirakis E, Stournas S, Zannikos F, Karonis D. Biodiesel emissions from a diesel vehicle operated on a non-legislative driving cycle. Energy Sources, Part A: Recovery, Utilization, and Environmental Effects. 2009;32(4):376-383.

[12] Schwarzer V, Ghorbani R. Drive cycle generation for design optimization of electric vehicles. IEEE Transactions on Vehicular Technology. 2013;62(1):89-97.

[13] Sharma R, Manzie C, Bessede M, Crawford RH, Brear MJ. Conventional, hybrid and electric vehicles for Australian driving conditions. Part 2: Life cycle CO 2-e emissions. Transportation Research Part C: Emerging Technologies. 2013;28:63-73. 
[14] Chrenko D. Influence of hybridisation on eco-driving habits using realistic driving cycles. IET Intelligent Transport Systems. 2015;9(5):498-504.

[15] Dai Z, Niemeier D, Eisenger D. Driving cycles: a new cycle-building method that better represents real-world emissions [Internet]. California: Department of Civil and Environmental Engineering, University of California; 2008 [cited 2013 July 26]. Available from: http:// www.dot.ca.gov/hq/env/air/research/ucd_aqp/Documents/2008-Dai-arterial-cycles-final.pdf

[16] Bishop JD, Axon CJ, McCulloch MD. A robust, data-driven methodology for real-world driving cycle development. Transportation Research Part D: Transport and Environment. 2012;17(5):389-397.

[17] Brady MJ, O'Mahony M. The development of a driving cycle for the greater Dublin area using a large database of driving data with a stochastic and statistical methodology. Proceedings of the ITRN2013; 2013 Sep 5-6; Dublin, Ireland.

[18] Tong HY, Hung WT. A framework for developing driving cycles with on-road driving data. Transport reviews. 2010;30(5):589-615.

[19] Amirjamshidi G, Roorda MJ. Development of simulated driving cycles for light, medium, and heavy duty trucks: Case of the Toronto Waterfront Area. Transportation Research Part D: Transport and Environment. 2015;34:255-266.
[20] Lipar P, Kostanjšek J, Filipič K, Milovanovič K. PAMS activity monitoring of light-duty vehicles: Recruitment of vehicles in the region of Ljubljana (Slovenia): Final Report. UL FGG, Prometnotehniški inštitut; 2009.

[21] Watson HC, Milkins EE, Braunsteins J. The development of the Melbourne peak cycle. Paper presented at: Second Conference on Traffic Energy and Emissions; 1982 May 19-20; Melbourne, Australia.

[22] Austin TC, Carlson TR, and Dulla RG. Methodology for Generating Driving Cycles for Inventory Development. Report No. SR95-09-02. Prepared for the U.S. Environmental Protection Agency. Sierra Research Inc. California, 66; 1995.

[23] Fincher S, Palacios C, Kishan S, Preusse D, Perez H. Modifying Link - Level Emissions Modeling Procedures for Applications within the MOVES Framework: Final Report. Federal Highway Administration; 2010 [cited 2013 June26]. Available from: http://www.fhwa.dot. gov/environment/air_quality/conformity/research/ modeling_procedures/procedures_rpt.pdf

[24] Barlow TJ, Latham S, McCrae IS, Boulter PG. A reference book of driving cycles for use in the measurement of road vehicle emissions: version 3. Bracknell: HIS; 2009 [cited 2103 April 12]. Available from: https:// www.gov.uk/government/uploads/system/uploads/ attachment_data/file/4247/ppr-354.pdf 